\title{
Inactivation of RIZ1 Gene by Promoter Hypermethylation is Associated with Disease Progression and Resistance to Imatinib in Indian Chronic Myelogenous Leukemia Patients, First Study from India
}

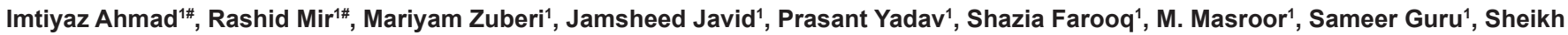
Shahnawaz ${ }^{1}$, P C Ray ${ }^{1}$, Ishfaq Ahmed Sheikh ${ }^{2}$, Tanvir Khatlani ${ }^{3}$, Ajaz Ah Bhat ${ }^{4}$, Naresh Gupta ${ }^{5}$, Sunita Jetly ${ }^{6}$, Niyaz Ahmad ${ }^{7}$ and Alpana Saxena ${ }^{8 *}$

${ }^{1}$ Molecular Oncology Lab, Department of Biochemistry, Maulana Azad Medical College and Associated hospitals, New Delhi, India

${ }^{2}$ King Fahd Medical Research Center, King Abdulaziz University, Jeddah, Saudia Arabia

${ }^{3}$ Department of Medicine, Thrombosis Research, Baylor College of Medicine, Houston TX, USA

${ }^{4}$ Division of Surgical Oncology, Vanderbilt University, Nashville, TN, USA

${ }^{5}$ Clinical haematology, Department of Medicine, LN hospital, MAMC, New Delhi, India

${ }^{6}$ Acharya Narendra Dev College, New Delhi, India

7Immunology and molecular medicine, SKIMS

${ }^{8}$ Director Professor and Head, Department of Biochemistry, Maulana Azad Medical College and Associated Hospitals, New Delhi 110002, India

${ }^{\#}$ Equal contribution

\begin{abstract}
Background: The epigenetic impact of DNA methylation in chronic myelogenous leukemia (CML) is not completely understood. RIZ1 expression and activity are reduced in many cancers. In CML, blastic transformation is associated with loss of heterozygosity in the region where RIZ1 is located. RIZ1 is a PR domain methyltransferase that methylates histone $\mathrm{H} 3$ lysine 9, a modification important for transcriptional repression. In CML blast crisis cell lines RIZ1 represses insulin-like growth factor-1 expression and autocrine signaling. Together these observations suggest that RIZ1 may have a role in the chronic phase to blast crisis transition in CML.
\end{abstract}

Methods: To examine whether promoter methylation is involved in the disease development and progression of $\mathrm{CML}$, we investigated promoter methylation status of RIZ1 gene in 100 chronic myeloid leukemia's (CML) patients and 50 controls by MSP method.

Results: The RIZ1 methylation was studied in $100 \mathrm{CML}$ patients, 9 were cases were methylation positive cases, six of nine were in blastic phase, 2 in chronic phase and one patient in accelerated phase. It was seen that RIZ1 methylation was increased significantly from early to advanced phase. The higher frequency of RIZ1 methylation was reported in haematologically resistant cases (42\% vs $2 \%)$ and molecularly resistant cases ( $16.77 \%$ vs $1.92 \%$ ) than the responders. The higher frequency of RIZ1 methylation was found in CML patients who were treated with interferon initially followed by imatinib treatment. Also RIZ1 hypermethylation was associated with faster disease progression $p<0.003$ than the non methylated cases. No correlation was found between RIZ1 gene methylation with age, thrombocytopenia, types of bcr/abl transcripts of CML patients.

Conclusion: We conclude that epigenetic silencing of RIZ1 gene is associated with CML progression and imatinib resistance. Early detection of RIZ1 methylation could be a predictive marker for imatinib resistance and disease progression in CML.

Keywords: Myelogenous leukemia; Methylation; Resistance; RIZ1 gene

Abbreviations: Retinoblastoma Protein: Interacting Zinc Finger gene (RIZ1); CML: Chronic Myeloid Leukemia; MS: MethylationSpecific PCR; TSGs: Tumour Suppressor Gene; CP-CML: Chronic Phase; AP- CML: Accelerated Phase \& BC- CML Blast Phase

\section{Introduction}

CML is a pluripotent haematopoietic stem cell disorder. Diagnosis of chronic myeloid leukemia is based on the detection of BCR$\mathrm{ABL}$ gene, a product derived from translocation of chromosome 22 to chromosome 9 [1]. It is detected in more than $95 \%$ of patients with chronic myeloid leukemia (CML), $20 \%$ to $40 \%$ in adult acute lymphoblastic leukemia (ALL) and $2 \%$ to $5 \%$ in paediatric ALL [2]. CML progresses at a varying rate from the $\mathrm{CP}$ to the $\mathrm{AP}$ and eventually to the BP [3]. However molecular mechanisms responsible for driving the transition of CML from chronic phase to blast crisis are not well characterized. Inactivation of TSGs plays an important role in cancer formation and progression. Either genetic or epigenetic mechanisms are known to inactivate TSGs. DNA methylation-induced silencing

*Corresponding author: Dr. Alpana Saxena, Director, Professor and Head, Department of Biochemistry, Maulana Azad Medical College and Associated Hospitals, New Delhi 110002, Tel: +91-9968584601; E-mail: drrashidmamc@gmail.com

Received November 04, 2012; Accepted December 26, 2012; Published December 28, 2012

Citation: Ahmad I, Mir R, Zuberi M, Javid J, Yadav P, et al. (2013) Inactivation of RIZ1 Gene by Promoter Hypermethylation is Associated with Disease Progression and Resistance to Imatinib in Indian Chronic Myelogenous Leukemia Patients, First Study from India. J Cancer Sci Ther 5: 045-051. doi:10.4172/1948-5956.1000183

Copyright: (C) 2013 Imtiyaz Ahmad AB, et al. This is an open-access article distributed under the terms of the Creative Commons Attribution License, which permits unrestricted use, distribution, and reproduction in any medium, provided the original author and source are credited. 
Citation: Ahmad I, Mir R, Zuberi M, Javid J, Yadav P, et al. (2013) Inactivation of RIZ1 Gene by Promoter Hypermethylation is Associated with Disease Progression and Resistance to Imatinib in Indian Chronic Myelogenous Leukemia Patients, First Study from India. J Cancer Sci Ther 5: 045-051. doi:10.4172/1948-5956.1000183

of gene expression is now recognized as an important contribution in all stages of carcinogenesis [4]. DNA methylation is a covalent chemical modification, resulting in the addition of a methyl $(\mathrm{CH} 3)$ group at the carbon 5 position of the cytosine ring. Even though most cytosine methylation occurs in the sequence context 5CG3 (also called the $\mathrm{CpG}$ dinucleotide), some involves $\mathrm{CpA}$ and $\mathrm{CpT}$ dinucleotides. Methylation of $\mathrm{CpG}$ islands within gene promoter regions can lead to silencing of gene expression [5]. DNA methylation of promoter region $\mathrm{CpG}$ islands may serve as an alternate mechanism to genetic defects in the inactivation of tumour suppressor genes in human malignancies [6]. Many cellular pathways are inactivated by this epigenetic event, including DNA repair, cell cycle, apoptosis, cell adherence, and detoxification [7]. Aberrant hypermethylation has been previously described in CML [8-10]. A few studies have examined the methylation status of individual TSGS in CML, with results ranging from rare or no hypermethylation (e.g., HOXA, SFRP1, RASSF1A) [11-13] to hypermethylation at progression (e.g., CALCA, CDKN2B, EBF2, ESR, HIC1, TFAP2A, and others [14-18]. RIZ is a member of the nuclear protein- methyltransferase superfamily. This family plays an important role in chromatin mediated regulation of gene expression, development and cancer. RIZ1 gene produces two protein products of different length, RIZ1 and RIZ2. RIZ1, a PR domain methyltransferase, is located at $1 \mathrm{p} 36$. RIZ1 contains the positive regulatory (positive regulatory domain I binding factor1) domain, but RIZ2 lacks this domain [19]. Thus, the PR domain is possibly responsible for the tumour suppressing activity of RIZ1. It methylates histone H3 lysine 9, a modification important for transcriptional repression [20]. In many human cancers, RIZ1 can induce G2-M arrest and apoptosis, hence considered as a TSG. Although RIZ1 is a putative tumour suppressor in several cancer types, for instance human hepatocellular carcinoma [21], gastric cancer [22], cholangiocarcinoma [23], thyroid carcinoma [24], pheochromocytomas and abdominal paragangliomas [25], human gastric carcinoma [26], parathyroid tumors and pheochromocytomas [27] and so on, the role of RIZ1 in chronic myeloid leukemia has not been reported yet.

\section{Material and Method}

Blood samples of $100 \mathrm{CML}$ patients were collected from Maulana Azad Medical College and Associated Hospitals, New Delhi. Patients were diagnosed clinically by bone marrow hyperplasia, leukocytosis, splenomegaly, high fever and fatigue. The diagnosis was also confirmed by detecting $\mathrm{t}(9 ; 22)$ or BCR/ABL fusion gene $\left(\mathrm{p} 210^{\mathrm{bcr}-\mathrm{abl}}\right)$ which is further categorized into b3a2 or b2a2 subtypes on the basis of the BCR breakpoint by Reverse transcription polymerase chain reaction in the molecular oncology lab.

\section{Molecular diagnosis}

\section{Selection criteria of patients:}

- Inclusion Criteria: The study included newly diagnosed CML patients treated with imatinib with a dose of $400 \mathrm{mg} /$ day. All three stages of cases were included, Chronic phase (CP), Accelerated phase (AP) ,Blast crisis (BC). The exclusion criteria included Chronic myelomonocytic leukemia's (CMML) patients, other myeloproliferative disorder patients. The patients follow up was maintained regularly and samples were collected after every six months for imatinib response and mutation studies. The classic criteria used for imatinib mesylate responses in chronic myeloid leukemia for hematologic and molecular responses are depicted in Table $1 \mathrm{~A}$ and $\mathrm{B}$.
Sample collection: Venous blood $(5 \mathrm{ml})$ or $1 \mathrm{ml}$ bone marrow aspirate was collected in EDTA vials from CML patients. Buffy coat was isolated and washed in red cells lysis buffer. All samples were stored at $-80^{\circ} \mathrm{C}$ until the RNA and genomic DNA was extracted.

RT-PCR for BCR-ABL: Total RNA was extracted from about $10^{6}$ white cells by Trizol assay (Invitrogen). For cDNA synthesis, the concentration of RNA was measured spectrophotometrically or by gel electrophoresis and then the cDNA was synthesized using M-MuLV Reverse Transcriptase and other reaction components (Fermentas). The two $\mu$ g of RNA was reverse transcribed with 200 units of M-MuLV $\mathrm{RT}$ in a reaction mix consisting of $1 \mathrm{x}$ RT buffer $(50 \mathrm{mM}$ Tris- $\mathrm{HCl}, 50$ $\mathrm{mM}, \mathrm{KCl}, 4 \mathrm{mM} \mathrm{MgCl}$, $10 \mathrm{mM}$ DTT), $0.5 \mathrm{~g}$ of oligo (dT), $20 \mathrm{mM}$ dNTP and 20 units RNase inhibitor, in a final volume of $20 \mu$. The thermocycling conditions were $70^{\circ} \mathrm{C}$ for $5 \mathrm{~min}, 37^{\circ} \mathrm{C}$ for $5 \mathrm{~min}, 42^{\circ} \mathrm{C}$ for $1 \mathrm{~h}$ and $70^{\circ} \mathrm{C}$ for $10 \mathrm{~min}$. The quality of RNA and efficiency of cDNA synthesis were analyzed by amplification of BCR gene as an internal control.

Multiplex RT -PCR: The cDNA product was amplified with $1 \mathrm{U} /$ $\mu \mathrm{L}$ Taq polymerase, $240 \mu \mathrm{M} \mathrm{dNTP}, 1.8 \mathrm{M} \mathrm{MgCl}_{2}$, and $0.6 \mu \mathrm{M}$ of the four primers (CA3, C5e, BCR-C, and B2B). Multiplex RT-PCR assay was performed on a PCR machine with the program of $10 \mathrm{sec}$ at $100^{\circ} \mathrm{C}$ one min at $96^{\circ} \mathrm{C}$, three min at $60^{\circ} \mathrm{C}$, two min at $72^{\circ} \mathrm{C}, 10 \mathrm{sec}$ at $100^{\circ} \mathrm{C}$, $20 \mathrm{sec}$ at $97^{\circ} \mathrm{C}, 25 \mathrm{sec}$ at $58^{\circ} \mathrm{C}, 25 \mathrm{sec}$ at $60^{\circ} \mathrm{C}, 10 \mathrm{sec}$ at $78^{\circ} \mathrm{C}, 50 \mathrm{sec}$ at $73^{\circ} \mathrm{C}$, and 31 times to step five and $10 \mathrm{~min}$ at $73^{\circ} \mathrm{C}$. The sequence of oligonucleotide primers used in multiplex RT-PCR for BCR-ABL fusion transcripts as the target gene and $\mathrm{BCR}$ transcripts as internal control are shown in Table 1. The primer combinations in multiplex RT-PCR allowed simultaneous detection of all known types of BCR$\mathrm{ABL}$ and $\mathrm{BCR}$ transcripts in one reaction [28]. The expected bands were as follows: 808bp, normal BCR; 481 bp, e1a2; 385bp ,b3a2;310bp, b2a2 The quality of RNA and efficiency of cDNA synthesis were analyzed by amplification of BCR gene as an internal control.

Methylation analysis: Genomic DNAs from tumour tissues and cell lines were extracted using universal Genomic DNA extraction Kit (Nucleopore).The quality and integrity of the DNA was determined

\begin{tabular}{|c|c|c|}
\hline $\begin{array}{l}\text { Complete or major } \\
\text { hematological response }\end{array}$ & $\begin{array}{l}\text { Partial or minor } \\
\text { hematological response }\end{array}$ & $\begin{array}{l}\text { Loos or minimal } \\
\text { hematological response }\end{array}$ \\
\hline $\begin{array}{l}\text { Platelet count }>150 \times 10^{9} / \mathrm{L} \\
\text { WBC count }<10 \times 10^{9} / \mathrm{L} \\
\text { Basophils : }<5 \% \\
\text { Differential without } \\
\text { immature granulocytes. } \\
\text { Absence of blasts } \\
\text { and promyelocytes in } \\
\text { peripheral blood } \\
\text { Spleen : nonpalpable } \\
\text { spleen }\end{array}$ & $\begin{array}{l}\text { Presence of blasts } \\
\text { and promyelocytes in } \\
\text { peripheral blood } \\
\text { Spleen : Palpable spleen }\end{array}$ & $\begin{array}{l}\text { Presence of blasts } \\
\text { and promyelocytes in } \\
\text { peripheral blood } \\
\text { Spleen : Palpable spleen }\end{array}$ \\
\hline
\end{tabular}

Table 1a: Hematologic responses.

\begin{tabular}{|l|l|}
\hline Major molecular response & Minimal or No Molecular response \\
\hline It indicates nonquantifiable and & It indicates quantifiable and detectable \\
nondetectable bcr-abl gene transcript & bcr-abl gene transcript (BCR-ABL/ABL) \\
(BCR-ABL/ABL) $\geq 0.10^{3}$ & $\geq 0.10^{3}$ \\
\hline l log reduction of $B C R-A B L / A B L$ & $N o 3$ log reduction of BCR-ABL/ABL \\
\hline
\end{tabular}

Table 1b: Molecular response. 
Citation: Ahmad I, Mir R, Zuberi M, Javid J, Yadav P, et al. (2013) Inactivation of RIZ1 Gene by Promoter Hypermethylation is Associated with Disease Progression and Resistance to Imatinib in Indian Chronic Myelogenous Leukemia Patients, First Study from India. J Cancer Sci Ther 5: 045-051. doi:10.4172/1948-5956.1000183

by the A260/280 ratios and by $2 \%$ gel electrophoresis. Genomic DNA $(1 \mu \mathrm{g})$ was modified with sodium bisulfite using EZ-DNA methylation kit (Zymo research). Bisulfite-treated DNA was used for methylationspecific PCR by using previously published primer sets 18 to distinguish between methylated and unmethylated DNA. The PCR products were electrophoresed on a $2 \%$ agarose gel.

Methylation-specific polymerase chain reaction: Methylationspecific primers were used to investigate the methylation status of samples as described by Du et al, [12]. Primers specific for methylated and unmethylated DNA alleles are depicted in the Table 2.

The thermo cycling conditions were 45 cycles of denaturation at $94^{\circ} \mathrm{C}$ for 30 s, annealing at $68^{\circ} \mathrm{C}$ for methylation-specific amplification or at $60{ }^{\circ} \mathrm{C}$ for unmethylation-specific amplification for $45 \mathrm{~s}$ and extension at $72{ }^{\circ} \mathrm{C}$ for $60 \mathrm{~s}$, then a final extension at $72{ }^{\circ} \mathrm{C}$ for 10 minutes. The PCR products were then analyzed on a $2.5 \%$ agarose gel. The expected bands were as follows: $177 \mathrm{bp}$ for methylated DNA and $175 \mathrm{bp}$ for unmethylated DNA.

Statistical analysis: Statistical analysis was performed using the SPSS 13.0 software package. Chi-square analysis and Fisher exact test were carried out to compare the difference of frequencies between groups of patients. Mann-Whitney's U-test was carried out to the difference of age, level of RIZ-1 and bcr/abl transcript between the methylated and the unmethylated groups. The correlation between the frequency of RIZ-1 promoter methylation and the clinical and hematologic parameters was analyzed with Spearman's rank correlation. For all analyses, the $P$-values were two-tailed, and a $P$-value of $<0.05$ was considered statistically significant.

\section{Results}

\section{Demographic characteristics of study population}

The demographic characteristics of study population are listed in Table 3. A total of 65 males and 35 females already diagnosed with CML were included in the study. Two age groups were made, patients with age $<45$ years included 36 cases, above $>45$ included 64 cases (Table 3 ).

\section{Methylation-specific polymerase chain reaction}

PCR products were analyzed on 3.5\% agarose gel and visualized under UV illumination. To verify successful bisulfite modification of the DNA, a sequence containing cytosines would not be amplified after bisulfite modification by using primers that would only give an

\begin{tabular}{|l|c|}
\hline BCR-ABL primer sequences & AT \\
\hline 5'-ATAGGATCCTTTGCAACCGGGTCTGAA-3' & \\
5'-ACAGAATTCCGCTGACCATCAATAAG-3' & $58^{\circ} \mathrm{C}$ \\
5-ACCGCATGTTCCGGGACAAAAG-3' & \\
5'-TGTTGACTGGCGTGATGTAGTTGCTTGG-3 & \\
\hline
\end{tabular}

Table 2: Sequence of oligonucleotides used in multiplex RT-PCR for detection of $\mathrm{BCR}-\mathrm{ABL}$ transcript as the target gene and BCR transcripts as the internal control.

\begin{tabular}{|l|c|c|c|}
\hline Primer sequence of RIZ-1 & Primer & AT & $\begin{array}{c}\text { Product } \\
\text { size }\end{array}$ \\
\hline 5'GTGGTGGTTATTGGGCGACGGC-3' & Methylated primer & $68^{\circ} \mathrm{C}$ & $177 \mathrm{bp}$ \\
5'-GCTATTTCGCCGACCCCGACG-3' & $\begin{array}{c}\text { Reverse primer } \\
\text { Unmethylated primer } \\
\text { 5'-TGGTGGTTATTGGGTGATGGT-3' } \\
\text { 5'-ACTATTTCACCAACCCCAAGA-3' }\end{array}$ & $60^{\circ} \mathrm{C}$ & $175 \mathrm{bp}$ \\
\hline
\end{tabular}

Table 3: Sequence of oligonucleotides used for methylated and unmethylated DNA.

\begin{tabular}{|c|c|c|}
\hline & Number & Percentage \\
\hline Patients & 100 & \\
\hline \multicolumn{3}{|l|}{ AGE OF THE SUBJECTS } \\
\hline Age $<45$ & 36 & $36 \%$ \\
\hline Age $>45$ & 64 & $64 \%$ \\
\hline \multicolumn{3}{|c|}{ GENDER OF THE SUBJECTS } \\
\hline Males & 65 & $65 \%$ \\
\hline Female & 35 & $35 \%$ \\
\hline \multicolumn{3}{|l|}{ STAGE OF THE DISEASE } \\
\hline CP-CML & 48 & $48 \%$ \\
\hline AP-CML & 28 & $28 \%$ \\
\hline BC-CML & 24 & $24 \%$ \\
\hline \multicolumn{3}{|c|}{ TYPE OF BCR-ABL TRANSCRIPTS } \\
\hline A2b2 & 31 & $31 \%$ \\
\hline A2B3 & 67 & $67 \%$ \\
\hline A2b2/ A2b3 & 2 & $2 \%$ \\
\hline \multicolumn{3}{|c|}{ MOLECULAR RESPONSES TO IMATINIB } \\
\hline MMR & 52 & $52 \%$ \\
\hline No MR & 48 & $48 \%$ \\
\hline \multicolumn{3}{|c|}{ HEMATOLOGICAL RESPONSES TO IMATINIB } \\
\hline MHR & 50 & $50 \%$ \\
\hline Minor HR & 10 & $10 \%$ \\
\hline Loss HR & 40 & $40 \%$ \\
\hline \multicolumn{3}{|c|}{ TYROSINE KINASE INHIBITOR THERAPY } \\
\hline Imatinib & 90 & $90 \%$ \\
\hline Imatinib & 7 & $7 \%$ \\
\hline Interferon & 3 & $3 \%$ \\
\hline \multicolumn{3}{|l|}{ THROMBOCYTOPENIA } \\
\hline Thrombocytopenia & 60 & $60 \%$ \\
\hline No Thrombocytopenia & 40 & $40 \%$ \\
\hline
\end{tabular}

Table 4: Clinicopathological features of CML patients and Cancer-free healthy controls.

amplified product if the cytosines in the template sequence were not converted to uracils. Samples that did not give a band were considered completely modified and further used for MSP analysis. Those cases were defined as methylation positive if their sample showed a visual band amplified with methylated specific primers, even if the band was faint. The product size of $177 \mathrm{bp}$ and $175 \mathrm{bp}$ were expected for methylated (M) and unmethylated (U) DNA of RIZ1 promoter methylation respectively. All positive results were confirmed in at least two MSP analysis (Figure 1).

\section{Frequency of RIZ-1 hypermethylation with respect to clinical parameters of the study population}

Nine patients (9\%) showed RIZ1 hypermethylation that was not found in any controls $(P<0.06)$ as depicted in Table 4 . There were no significant correlations between the methylation status of RIZ1 hypermethylation and the clinical features such as age, sex, thrombocytopenia, chromosomal abnormalities like BCR-ABL and its transcripts.

\section{Frequency of RIZ-1 hypermethylation with respect to type of BCR-ABL transcript}

We were able to reliably detect typical p210 transcripts, such b2a2 or b3a2 transcripts in 100 patients at the presentation, b3a2 transcript was detected in $67 \%$ cases, b2a 2 in $31 \%$ and both b3a 2 and b2a 2 in $2 \%$ patients. Among males $67.6 \% 29.2 \%$ and $3.07 \%$ showed b3a2, b2a2 and 
Citation: Ahmad I, Mir R, Zuberi M, Javid J, Yadav P, et al. (2013) Inactivation of RIZ1 Gene by Promoter Hypermethylation is Associated with Disease Progression and Resistance to Imatinib in Indian Chronic Myelogenous Leukemia Patients, First Study from India. J Cancer Sci Ther 5: 045-051. doi:10.4172/1948-5956.1000183

both b3a2/b2a2 transcript respectively. Among females $65.7 \%, 34.2 \%$ showed b3a2, b2a2 respectively. However no significant correlation was found between BCR-ABL transcript type and RIZ1 promoter methylation.

\section{RIZ-1 methylation is increased in blast crisis or advanced stage CML patients}

Among the 100 CML patients at the time of analysis, 48 were in chronic phase, 28 in accelerated phase and 24 in blast crisis respectively. RIZ1 promoter was methylated in $9 \%$ of CML patients. Six out of 9 patients were in blastic phase, 1 in accelerated phase and 2 in chronic phase CML. A significant difference was found between the frequency of RIZ-1 methylation and CML stages $(P<0.05)$ as depicted in Table 5. Among the 2 patients in chronic phase having RIZ1 promoter methylation one patient showed transition from chronic phase to blastic phase indicating that RIZ1 inactivation might be one main factor for disease progression. RIZ1 promoter methylation was increased significantly from early to advanced phase in our CML patients .The high frequency of RIZ-1 hypermethylation in blast crisis may suggest that aberrant methylation is a non-specific, global process that is a feature of advanced phase chronic myeloid leukemia, at least in a subset of patients.

\section{RIZ-1 methylation is increased in hematological resistant CML patients}

Among $100 \mathrm{CML}$ patients at the time of analysis, 50 display major HR, 10 minor HR and 40 minimal haematological responses respectively. The higher frequency of RIZ1 promoter methylation was reported in minor HR (30\%), minimal HR (12.50\%) followed by major $(2 \%)$ hematological responders. A significant difference $(\mathrm{P}<0.01)$ was reported between RIZ1 methylation and haematological resistances in CML patients.

\section{RIZ-1 methylation is increased in molecular resistant (BCR- $\mathrm{ABL} / \mathrm{ABL}>0.50 \%$ ) CML patients}

Among the 100 CML patients at the time of analysis, 52 displayed major MR, 48 minimal or no molecular responses. The higher frequency of RIZ1 promoter methylation was reported in molecular resistant cases $(16.77 \%)$ than the good molecular responders $(1.92 \%)$ i.e., ( $16.77 \%$ vs $1.92 \%)$. The significant difference was reported between

\begin{tabular}{|c|c|c|c|c|c|c|}
\hline Clinical feature & $\mathbf{N}$ & $\begin{array}{c}\text { RIZ1 } \\
\text { unmethylated }\end{array}$ & $\%$ & $\begin{array}{c}\text { RIZ1 } \\
\text { methylated }\end{array}$ & $\%$ & P Value \\
\hline Patients & 100 & 91 & $91 \%$ & 9 & $9 \%$ & 0.06 \\
\hline Controls & 50 & 50 & $100 \%$ & 0 & $0 \%$ & \\
\hline Age $>45$ & 36 & 33 & $91.6 \%$ & 3 & $8.4 \%$ & 0.98 \\
\hline Age $<45$ & 64 & 58 & $90.6 \%$ & 6 & $9.4 \%$ & \\
\hline Males & 65 & 58 & $89.2 \%$ & 7 & $10.7 \%$ & 0.63 \\
\hline Female & 35 & 33 & $94.2 \%$ & 2 & $5.8 \%$ & \\
\hline CP-CML & 48 & 46 & $95.8 \%$ & 2 & $4.2 \%$ & \\
\hline AP-CML & 28 & 27 & $96.4 \%$ & 1 & $3.6 \%$ & 0.009 \\
\hline BC-CML & 24 & 18 & $75 \%$ & 6 & $25 \%$ & \\
\hline b2a2 & 31 & 29 & $93.5 \%$ & 2 & $6.5 \%$ & \\
\hline b3a2 & 67 & 60 & $89.5 \%$ & 7 & $10.5 \%$ & 0.73 \\
\hline $\mathrm{A} 2 \mathrm{~b} 2 / \mathrm{A} 2 \mathrm{~b} 3$ & 2 & 2 & $100 \%$ & 0 & $0 \%$ & \\
\hline MMR & 52 & 51 & $98.08 \%$ & 01 & $1.92 \%$ & 0.03 \\
\hline Loss of MR & 48 & 40 & $83.33 \%$ & 8 & $16.77 \%$ & \\
\hline MHR & 50 & 49 & $98 \%$ & 01 & $2 \%$ & 0.01 \\
\hline Minor HR & 10 & 07 & $70 \%$ & 03 & $30 \%$ & \\
\hline Minimal HR & 40 & 35 & $85 \%$ & 05 & $12.50 \%$ & \\
\hline Imatinib alone & 90 & 84 & $93.33 \%$ & 6 & $6.66 \%$ & 0.02 \\
\hline Imatinib+Dasatanib & 07 & 06 & $85.70 \%$ & 1 & $14.30 \%$ & \\
\hline Interferon & 03 & 01 & $33.33 \%$ & 2 & $66.66 \%$ & \\
\hline Thrombocytopenia & 60 & 54 & $90 \%$ & 6 & $10 \%$ & 0.9 \\
\hline No Thrombocytopenia & 40 & 37 & $92.5 \%$ & 3 & $7.5 \%$ & \\
\hline
\end{tabular}

MR:Molecular response, HR: Hematological response

Table 5: Correlation between RIZ-1 promoter methylation and the clinical characteristics of CML patients. 
Citation: Ahmad I, Mir R, Zuberi M, Javid J, Yadav P, et al. (2013) Inactivation of RIZ1 Gene by Promoter Hypermethylation is Associated with Disease Progression and Resistance to Imatinib in Indian Chronic Myelogenous Leukemia Patients, First Study from India. J Cancer Sci Ther 5: 045-051. doi:10.4172/1948-5956.1000183

the molecular resistant cases and cases with RIZ1 hypermethyaltion $(<0.03)$.

\section{RIZ-1 methylation is increased in CML patients treated with interferon initially}

It is established now that RIZ1 DNA methylation is increased in imatinib resistant and advanced stage or progressed cases. The higher frequency of RIZ1 promoter methylation was found in CML patients who were treated with interferon initially followed by imatinib treatment. The significant difference was reported among the three groups and cases with RIZ1 hypermethyaltion $(<0.03)$.

\section{RIZ1 hypermethyaltion induced faster disease progression and shorter survival}

Follow-up of patients regarding disease progression in terms of survival was performed with median duration of 80 months. A total of 52 patients suffered progression with mean follow up time of 4 years. It was observed that the RIZ1 hypermethyaltion cases were significantly associated with faster disease progression $\mathrm{p}<0.003$ (Figure 2).

Since imatinib treatment changed radically the outcome of CML, we analyzed separately the groups of patients treated before and in the imatinib era. Our results suggest that epigenetic aberrations in RIZ1 gene may result in a blockage of apoptotic and differentiation pathways, which causes expansion of the myeloid blast cell population. Hypermethylation of tumour suppressor RIZ1 may be a therapeutic target. However, more extensive pre-clinical and clinical studies incorporating demethylating agents are needed to assess their therapeutic role in chronic myeloid leukemia blast crisis.

\section{Discussion}

The frequency of hypermethylation of tumour suppressor gene RIZ1 in CML blast crisis is not known. One possible explanation is that the RIZ1 promoter $\mathrm{CpG}$ island is aberrantly hypermethylated. In the CML blast crisis cell line, K562, the RIZ1 promoter is hypermethylated and addition of a methylation inhibitor, 5-aza-2'-deoxycytidine, induces RIZ1 expression, Dong W et al. [20]. Epigenetic silencing has also been reported to reduce RIZ1 expression in other cancers Du Y et al. [18]. Molecular mechanisms responsible for driving the transition of CML from chronic phase to blast crisis are not well characterized. CML evolves from a chronic phase that is associated with the Philadelphia chromosome to a blast crisis phase, which is associated with additional chromosome or molecular aberrations.

Evolution to blast crisis is correlated with frequent loss of heterozygosity at chromosome region $1 \mathrm{p} 36$. Tumour suppressor gene silencing is important in progression of cancers. RIZ1, a PR domain methyltransferase, is located at 1p36. RIZ1 methylates histone $\mathrm{H} 3$ lysine 9, a modification important for transcriptional repression RIZ1 is a candidate tumour suppressor gene and its expression has been found to be lost in many cancers. RIZ1 expression and activity are reduced in many human cancers by genetic and epigenetic mechanisms.

RIZ1 expression is reduced in acute myeloid leukemia [20] and the RIZ1 knockout mouse has a high incidence of diffuse large B-cell lymphoma [16]. RIZ1 also regulates IGF-1 signaling in CML blast crisis cell lines and its expression has been found to be down regulated in CML blast crisis [29]. Mechanism for decreased RIZ1 expression in CML is not known. The RIZ1 promoter has been demonstrated to have the characteristics of a CpG island, which suggests that RIZ1 is a target of inactivation by epigenetic mechanisms [19].

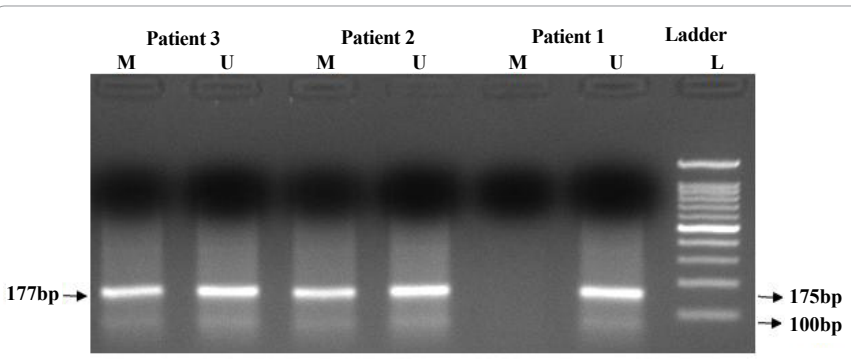

Figure 1: Representative data showing the methylation status of RIZ-1 gene $\mathrm{M}$, methylated DNA; U, unmethylated DNA; ladder, 100bp DNA molecular ladder.

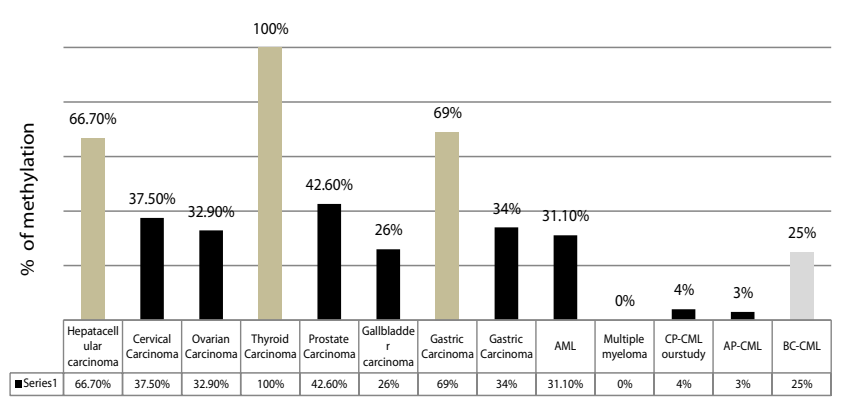

Figure 2: Frequency of RIZI methylation in different malignancies in the world

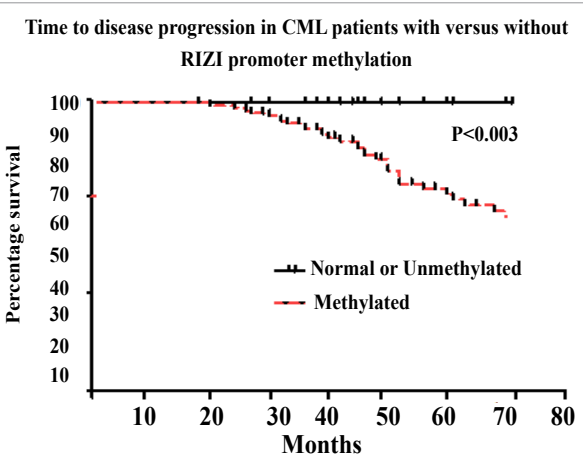

Figure 3: RIZ1 hypermethyaltion cases were significantly associated with faster disease progression.

In the CML blast crisis cell line, K562, the RIZ1 promoter is hypermethylated and addition of a methylation inhibitor, 5-aza-2'deoxycytidine, induces RIZ1 expression [29]. In our study we found $9 \%$ of CML patients with RIZ1 promoter methylation, $25 \%$ of blastic phase cases were found methylated compared to $3.6 \%$ and $4.2 \%$ in accelerated and chronic phases respectively.

RIZ1 promoter methylation was methylated in 100\% thyroid Carcinoma cases in USA, 79\% Hepatocellular carcinoma cases in Japan, $66.70 \%$ hepatocellular carcinoma in China, 69\% Gastric carcinoma in Japan ,30\% in AML cases in Japan and $0 \%$ of multiple myeloma cases Honkong as depicted in the Figure 3.

Both genetic and epigenetic changes contribute to development of human cancer. Oncogenomics has primarily focused on understanding the genetic basis of neoplasia, with less emphasis being placed on the role of epigenetics in tumourigenesis. Genomic alterations in cancer vary between the different types and stages, tissues and individuals. 
Citation: Ahmad I, Mir R, Zuberi M, Javid J, Yadav P, et al. (2013) Inactivation of RIZ1 Gene by Promoter Hypermethylation is Associated with Disease Progression and Resistance to Imatinib in Indian Chronic Myelogenous Leukemia Patients, First Study from India. J Cancer Sci Ther 5: 045-051. doi:10.4172/1948-5956.1000183

Moreover, genomic change ranges from single nucleotide mutations to gross chromosomal aneuploidy; which may or may not be associated with underlying genomic instability.

Collectively, genomic alterations result in widespread deregulation of gene expression profiles and the disruption of signalling networks that control proliferation and cellular functions. In addition to changes in DNA and chromosomes, it has become evident that oncogenomic processes can be profoundly influenced by epigenetic mechanisms. DNA methylation is one of the key epigenetic factors involved in regulation of gene expression and genomic stability, and is biologically necessary for the maintenance of many cellular functions. While there has been considerable progress in understanding the impact of genetic and epigenetic mechanisms in tumourigenesis, there has been little consideration of the importance of the interplay between these two processes. In this review we summarize current understanding of the role of genetic and epigenetic alterations in human cancer.

It is possible that gene silencing provides an alternative to BCR-ABL mutations in conferring imatinib resistance. Indeed, only about $50 \%$ of imatinib resistance can be conclusively traced to acquired mutations. It will therefore be worthwhile to study mutations and methylation simultaneously and determine whether there is an inverse correlation between the two events, and whether it is relevant to resistance to other tyrosine kinase inhibitors.

It is also interesting to consider the fact that DNA methylation can be partially reversed by treatment with decitabine or azacitidine. Decitabine has demonstrated single-agent activity in CML, [30] and a combination of decitabine and imatinib has shown a promising response rate in AP and BP. Given that many patients with blasticphase CML continue to die of their disease, such drug combinations may be relevant even after therapy with second-generation tyrosine kinase inhibitors.

\section{Conclusion}

We conclude that aberrant methylation of RIZ1 gene is associated with disease progression and that DNA methylation could be a marker associated with imatinib resistance. Early detection of RIZ1 methylation may help identify a subset of CML patients that would benefit from treatment with demethylating agents.

\section{Acknowledgment}

We thank India Council of Medical Research for providing us grant.

\section{References}

1. Sawyers CL (1999) Chronic myeloid leukemia. N Engl J Med 340: 1330-1340.

2. Crist W, Carroll A, Shuster J, Jackson J, Head D, et al. (1990) Philadelphia chromosome positive childhood acute lymphoblastic leukaemia: Clinical and cyotogenetic characteristic and treatment outcome. A Paediatric Oncology Group study. Blood, 76: 489-494.

3. Issa JP, Gharibyan V, Cortes J, Jelinek J, Morris G, et al. (2005) Phase II study of low-dose decitabine in patients with chronic myelogenous leukemia resistant to imatinib mesylate. J Clin Oncol 23: 3948-3956.

4. Jones PA, Baylin SB (2002) The fundamental role of epigenetic events in cancer. Nat Rev Genet 3: 415-428.

5. Jones PA, Laird PW (1999) Cancer epigenetics comes of age. Nat Genet 21: 163-167.

6. Ramsahoye BH, Biniszkiewicz D, Lyko F, Clark V, Bird AP, et al. (2000) NonCpG methylation is prevalent in embryonic stem cells and may be mediated by DNA methyltransferase 3a. Proc Natl Acad Sci U S A 97: 5237-5242.

7. Esteller M, Corn PG, Baylin SB, Herman JG (2001) A gene hypermethylation profile of human cancer. Cancer Res 61: 3225-3229.
8. Strathdee G, Holyoake TL, Sim A, Parker A, Oscier DG, et al. (2007) Inactivation of HOXA genes by hypermethylation in myeloid and lymphoid malignancy is frequent and associated with poor prognosis. Clin Cancer Res 13: 5048-5055.

9. Pehlivan M, Sercan Z, Sercan HO (2009) sFRP1 promoter methylation is associated with persistent Philadelphia chromosome in chronic myeloid leukemia. Leuk Res 33: 1062-1067.

10. Avramouli A, Tsochas S, Mandala E, Katodritou E, loannou M, et al. (2009) Methylation status of RASSF1A in patients with chronic myeloid leukemia. Leuk Res 33: 1130-1132.

11. Nelkin BD, Przepiorka D, Burke PJ, Thomas ED, Baylin SB (1991) Abnorma methylation of the calcitonin gene marks progression of chronic myelogenous leukemia. Blood 77: 2431-2434.

12. Nguyen TT, Mohrbacher AF, Tsai YC, Groffen J, Heisterkamp N, et al. (2000) Quantitative measure of $\mathrm{c}-\mathrm{abl}$ and $\mathrm{p} 15$ methylation in chronic myelogenous leukemia: biological implications. Blood 95: 2990-2992.

13. Dunwell T, Hesson L, Rauch TA, Wang L, Clark RE, et al. (2010) A genomewide screen identifies frequently methylated genes in haematological and epithelial cancers. Mol Cancer 9: 44.

14. Carling T, Kim KC, Yang XH, Gu J, Zhang XK, et al. (2004) A histone methyltransferase is required for maximal response to female sex hormones. Mol Cell Biol 24: 7032-7042.

15. Steele-Perkins G, Fang W, Yang XH, Van Gele M, Carling T, et al. (2001) Tumor formation and inactivation of RIZ1, an Rb-binding member of a nuclear protein-methyltransferase superfamily. Genes Devel 15: 2250-2262.

16. Sasaki O, Meguro K, Tohmiya Y, Funato T, Shibahara S, et al. (2002) Altered expression of retinoblastoma protein-interacting zinc finger gene, RIZ, in human leukaemia. Br J Haematol 119: 940-948.

17. Ball MP, Li JB, Gao Y, Lee JH, LeProust EM, et al. (2009) Targeted and genome-scale strategies reveal gene-body methylation signatures in human cells. Nat Biotechnol 27: 361-368.

18. Du Y, Carling T, Fang W, Piao Z, Sheu JC, et al. (2001) Hypermethylation in human cancers of the RIZ1 tumor suppressor gene,a member of a histone/ protein methyltransferase superfamily.Cancer Res 61: 8094-8099.

19. Lakshmikuttyamma A, Takahashi N, Pastural E, Torlakovic E, Amin HM, et al (2009) RIZ1 is potential CML tumour suppressor that is down-regulated during disease progression. J Haematol Oncol 2.

20. Dong W, Scott SA, Guo Y, Bergen S, Sheridan D, et al. (2003) RIZ1, a protein histone methyltransferase superfamily member, is epigenetically silenced in human AML and its constitutive expression promotes apoptosis and differentiation. Blood 102:2134.

21. Fang W, Piao Z, Buyse IM, Simon D, Sheu JC, et al. (2001) Preferential loss of a polymorphic RIZ allele in human hepatocellular carcinoma. $\mathrm{Br} \mathrm{J}$ Cancer 84: 743-747.

22. Tokumaru Y, Nomoto S, Jerónimo C, Henrique R, Harden S, et al. (2003) Biallelic inactivation of the RIZ1 gene in human gastric cancer. Oncogene 22 6954-6958.

23. Khaenam P, Jearanaikoon $P$, Pairojkul C, Bhudhisawasdi V, Limpaiboon T (2010) Genetic and epigenetic alterations of RIZ1 and the correlation to clinicopathological parameters in liver fluke-related cholangiocarcinoma. Exp Ther Med 1: 385-390.

24. Lal G, Padmanabha L, Smith BJ, Nicholson RM, Howe JR, et al. (2006) RIZ1 is epigenetically inactivated by promoter hypermethylation in thyroid carcinoma. Cancer 107: 2752-2759.

25. Geli J, Nord B, Frisk T, Edström Elder E, Ekström TJ, et al. (2005) Deletions and altered expression of the RIZ1 tumour suppressor gene in 1p36 in pheochromocytomas and abdominal paragangliomas. Int J Oncol 26: 13851391.

26. Oshimo Y, Oue N, Mitani Y, Nakayama H, Kitadai Y, et al. (2004) Frequent epigenetic inactivation of RIZ1 by promoter hypermethylation in human gastric carcinoma. Int J Cancer 110: 212-218.

27. Carling T, Du Y, Fang W, Correa P, Huang S (2003) Intragenic allelic loss and 
Citation: Ahmad I, Mir R, Zuberi M, Javid J, Yadav P, et al. (2013) Inactivation of RIZ1 Gene by Promoter Hypermethylation is Associated with Disease Progression and Resistance to Imatinib in Indian Chronic Myelogenous Leukemia Patients, First Study from India. J Cancer Sci Ther 5: 045-051. doi:10.4172/1948-5956.1000183

promoter hypermethylation of the RIZ1 tumor suppressor gene in parathyroid tumors and pheochromocytomas. Surgery 134: 932-939.

28. Hassan R, Ramli M, Abdullah WZ, Mustaffa R, Ghazali S. et al. (2008) One step multiplex RT-PCR for BCR-ABL gene in Malaysian patients diagnosed as leukaemia Malaysian Journal of Medical Sciences, 12(suppl 1): 153.

29. Pastural E, Takahashi N, Dong WF, Bainbridge M, Hull A, et al. (2007) RIZ1 repression is associated with insulin-like growth factor-1 signaling activation in chronic myeloid leukemia cell lines. Oncogene 26: 1586-1594.

30. Oki Y, Kantarjian HM, Gharibyan V, Jones D, O'brien S, et al. (2007) Phase II study of low-dose decitabine in combination with imatinib mesylate in patients with accelerated or myeloid blastic phase of chronic myelogenous leukemia. Cancer 109: 899-906. 